\title{
Correction to: What is a phenotype? History and new developments of the concept
}

\section{Dominique de Vienne ${ }^{1}$ (1)}

Published online: 16 December 2021

(c) Springer Nature Switzerland AG 2021

\section{Correction to: Genetica}

https://doi.org/10.1007/s10709-021-00134-6

Due to errors that occurred during typesetting, it was necessary to update the article. The publisher apologises for these errors.
The original article has been corrected.

Publisher's Note Springer Nature remains neutral with regard to jurisdictional claims in published maps and institutional affiliations.

The original article can be found online at https://doi.org/10.1007/ s10709-021-00134-6.

Dominique de Vienne

dominique.de-vienne@inrae.fr

1 GQE-Le Moulon, INRAE, Centre National de la Recherche Scientifique, AgroParisTech, Université Paris-Saclay,

Gif-sur-Yvette, France 